\title{
JUAN DE VALDÉS LEAL, BERNARDO SIMÓN DE PINEDA Y EL RETABLO MAYOR DE LA IGLESIA DEL HOSPITAL DE LA MISERICORDIA DE SEVILLA
}

\author{
José Roda PEÑA ${ }^{1}$ \\ Universidad de Sevilla
}

\begin{abstract}
Se documenta y estudia la génesis y el desarrollo del proceso constructivo del retablo mayor de la iglesia del hospital de la Misericordia de Sevilla, obra del maestro ensamblador Bernardo Simón de Pineda entre 1668 y 1670, así como el verdadero papel desempeñado por el pintor Juan de Valdés Leal en los momentos iniciales de su diseño y contratación. Asimismo, se analizan los canales y mecanismos empleados para la financiación del conjunto retablístico, así como su ulterior dorado y policromía por parte de Miguel Delgado Moreno y Domingo Martínez en 1723-1724.

Palabras clave: Hospital de la Misericordia de Sevilla; retablo mayor; siglo XVII; Bernardo Simón de Pineda; Juan de Valdés Leal; Pedro Roldán; Miguel Delgado Moreno; Domingo Martínez.
\end{abstract}

\section{JUAN DE VALDÉS LEAL, BERNARDO SIMÓN DE PINEDA AND THE HIGH ALTARPIECE OF THE CHURCH OF THE HOSPITAL OF MERCY OF SEVILLE}

The author documents and studies the genesis and development of the constructive process of the high altarpiece of the church of the Hospital of Mercy of Seville, a work by the master assembler Bernardo Simón de Pineda between 1668 and 1670, as well as the true role played by the painter Juan de Valdés Leal in the initial moments of its design and contracting. Likewise analysed are the channels and mechanisms used for financing such an altarpiece, and its subsequent gilding and polychromy by Miguel Delgado Moreno and Domingo Martínez in 1723-1724.

Key words: Seville Mercy Hospital; high altarpiece; $17^{\text {th }}$ century; Bernardo Simón de Pineda; Juan de Valdés Leal; Pedro Roldán; Miguel Delgado Moreno; Domingo Martínez.

Cómo citar este artículo / Citation: Roda Peña, José (2018): “Juan de Valdés Leal, Bernardo Simón de Pineda y el retablo mayor de la iglesia del hospital de la Misericordia de Sevilla”. En: Archivo Español de Arte, vol. 91, núm. 363, Madrid, pp. 237-252. https://doi.org/10.3989/aearte 2018.15.

Situada en la histórica collación de San Andrés, la iglesia "nueva" del Hospital de la Misericordia de Sevilla se construyó entre 1598 y 1605, siguiendo las trazas suministradas por el arquitecto granadino y maestro mayor de la catedral hispalense Asensio de Maeda ${ }^{2}$. En el testero de su capilla mayor se dispuso un dosel de damasco carmesí guarnecido de galones, cintas y cordeles de hilos de oro y seda, que servía de respaldo a un Crucificado escultórico que se adquirió el referido año de 1605 por 9350 maravedís al prepósito de la Compañía de Jesús en la capital hispalense, procedente de su casa profesa ${ }^{3}$, que al efecto tuvo que ser nuevamente poli-

\footnotetext{
${ }^{1}$ roda@us.es / ORCID iD: http://orcid.org/0000-0002-4141-1178.

2 Serrera, 1995: 75. Albardonedo, 2003: 67-105.

3 Albardonedo, 2003: 92-93.
} 
cromado por el pintor portugués Vasco Pereira (1535-1609) ${ }^{4}$. Para completar el amueblamiento litúrgico de este espacio, la hermandad encargada de regir desde finales del siglo XV este establecimiento benéfico - dedicado fundamentalmente a la dotación de doncellas pobres y desamparadas para que pudiesen contraer matrimonio ${ }^{5}$ - encomendó al renombrado escultor Juan Martínez Montañés (1568-1649) y a Vasco Pereira la realización de un sagrario o "tabernáculo" para entronizar al Santísimo Sacramento en el altar mayor, recibiendo entre mayo y agosto de 1606 un total de 26180 maravedís "por la madera, manifatura, pintura y dorado" del mismo, quedando rematado por una pequeña cruz de plata ${ }^{6}$. Poco después se incorporaron al presbiterio una argéntea lámpara que debía estar ardiendo permanentemente delante del Santísimo, labrada por el platero Miguel Sánchez con un coste de 40800 maravedís abonados el 15 de noviembre de 1606, y dos blandones de madera de borne por los que se pagaron 4964 maravedís, amén de tres juegos de ornamentos necesarios para decir misa - carmesí, verde y morado, compuesto cada uno de "casulla, estola, manípulo y alba y amito y frontal con frontalera y mangas de terçiopelo con flecos de oro y seda y lo demás de damasco"-, que ingresaron en la sacristía 7

En cabildo extraordinario celebrado el 17 de octubre de 1650, los oficiales que componían la junta de gobierno de esta Casa de la Misericordia trataron por primera vez de la necesidad "de aser un retablo en el altar mayor della", acordándose que "se haga y que para esto se vaian disponiendo plantas por los artífices que lo pueden aser", debiéndose revisar aquellas en una nueva sesión capitular y "que se elija la que paresiere más a propósito y después se saque a pregón para que por vajas se rremate en el menor precio que fuere posible y que desde luego se avise a los escultores para que si fuere posible en el primer domingo de noviembre estén hechas las plantas"8.

Lo cierto es que el asunto no se retomó hasta el cabildo de 25 de febrero de 1668, en que Diego Caballero de Cabrera, miembro de la Orden de Alcántara, y a la sazón padre mayor - primera autoridad entre los cofrades de la Misericordia, pertenecientes muchos de ellos a la nobleza y oligarquía local-, presentó un memorial donde ponía de manifiesto que el haberse dilatado durante dieciocho años la resolución del acuerdo anterior no había hecho sino empeorar la conservación del ya mencionado dosel textil que, a pesar de haber sido objeto de diversas reparaciones, "está oy tan roto y tan indecente que es forçoso haçerle nuevo", cuyo importe se excusaría si por fin se procedía a la confección del retablo mayor. Confiesa Diego Caballero que, deseando cumplir con esta obligación, "a soliçitado que Juan de Valdés haga la planta", mostrándosela seguidamente a "personas de satisfaçión", quienes le comentaron "que por el precio que está tratado no pareçe posible poder haçer más", y es que, "aunque quisiera que tubiese la grandesa competente para esta Santa Casa, por lo menos será igual a la hospitalidad que professa, cubriendo toda la testera de alto abajo, en que se ahorrará una colgadura en las fiestas [...] y estará por lo menos con la decençia possible, mayormente quando se haçe sin que a esta Casa ni a sus dotaçiones cueste un solo real"'.

El artista al que se había dirigido el padre mayor para requerirle la elaboración de una traza del futuro retablo mayor era el renombrado pintor Juan de Valdés Leal (1622-1690), de quien ya conocíamos su puntual dedicación al campo de la representación gráfica aplicada al diseño de este género de ensambladuras, gracias a la existencia de varios de sus dibujos, como los conservados en la Courtauld Gallery de Londres (D. 1952. RW. 4457) y en el Cabinet des Dessins del

\footnotetext{
${ }^{4}$ Transcrita por Serrera, 1995: 77-78 y por Albardonedo, 2003: 85 y 91. Estoy de acuerdo con este último autor en que dicha escultura puede identificarse con el Cristo de mediados del siglo XVI y de tamaño algo menor al natural que, fijo a una cruz cepillada, recibe culto en un retablo rococó localizado en el muro del lado del evangelio de este templo.

5 Collantes de Terán, 1886: 123-149. Zahino, 1992: 63-80. Carmona, 2000: 146-147. Pérez, 2014: 25-44.

${ }^{6}$ Albardonedo, 2003: 93.

7 Albardonedo, 2003: 93-94. Ninguno de aquellos enseres de talla, plata y textiles se conserva en la actualidad.

8 Archivo Histórico Provincial de Sevilla (AHPSE), Hospital de la Misericordia, Libro 17, Libro de Acuerdos 1649 1655 , f. $108 \mathrm{v}$.

9 AHPSE, Hospital de la Misericordia, Libro 19, Libro de Acuerdos 1666-1675, f. 66r.
} 
Louvre (RF 43253) ${ }^{10}$; a ello debe añadirse la reputación que adquirió como tracista de arquitecturas efímeras, caso de las erigidas en la catedral de Sevilla en 1671 con motivo del nuevo culto a San Fernando ${ }^{11}$.

En ese preciso momento, la Casa de la Misericordia solo estaba en condiciones de disponer, sin comprometer su propia economía, de 500 ducados para materializar el ansiado proyecto del retablo mayor de su iglesia. Sin duda, se trataba de una cantidad bastante modesta en relación al espacio que dicha máquina lignaria debía cubrir, y a la que había tenido que someterse Valdés Leal a la hora de presentar un proyecto que quizás no resultaba tan majestuoso y deslumbrante como lo hubieran deseado sus cofrades para "la grandesa competente" de su templo, aunque al menos sí igualaba dignamente "la hospitalidad que professa". Aquel montante resultaba de sumar los 200 ducados que para dicho efecto había legado el difunto comerciante con Indias Bernaldo de Valdés, más los 100 que tenía prometido entregar Antonio del Castaño Camargo, otros 50 que donaría el abogado de la Real Audiencia de Sevilla y consultor del Santo Oficio de la Inquisición Francisco Ortiz de Godoy, 20 ducados que aún no se habían cobrado y que dejó en su testamento el caballero santiaguista y veinticuatro de Sevilla Alonso Verdugo de la Cueva - sobrino del famoso poeta Juan de la Cueva-, otra manda sin determinar del alguacil mayor de la Inquisición Juan de Saavedra Alvarado y 100 ducados que aportaría una persona cuyo nombre se silencia y "que entregará a Juan de Baldés el día que hiziere la escriptura, para que compre la madera como lo tiene tratado". Interesante asiento este último, dado que nos revela la intención de escriturar la ejecución del retablo con su diseñador, Valdés Leal, como lo confirma el hecho de que el padre mayor, Diego Caballero de Cabrera, tras hacer recuento de los aludidos recursos económicos, atestigua que "estos son los efectos con que oy nos hallamos y lo que a podido ajustar con Juan de Valdés que nos a de dar el retablo acavado, dorado y perfiçionado a toda costa, en conformidad de la planta, adornando toda la fachada de la testera"12.

Este crucial testimonio viene a reconocer, cuando menos, la capacidad de Valdés Leal para gestionar todo el proceso constructivo del retablo mayor, desde la compra de la madera hasta entregarlo "acavado, dorado y perfiçionado". No existe constancia de que Valdés —por mucho que Palomino lo reconociese como "escultor excelente", que se le denomine en algunas escrituras públicas como "maestro de escultor", que adquiriese en enero de 1666 herramientas y modelos en yeso, cera y barro en la almoneda de los bienes del escultor flamenco José de Arce, y de que se le hayan documentado algunas imágenes en terracota y en madera ${ }^{13}$-, llegara a contar con un taller propio que le permitiese acometer una máquina lignaria de estas características; más bien nos inclinamos por pensar que si en efecto hubiera obtenido formalmente algún encargo de este tipo, habría empleado sus frecuentes contactos laborales con ensambladores y escultores de absoluta solvencia para afrontarlo conjuntamente - aunque fuese bajo su dirección —, en función de sus respectivas especialidades artísticas, con plena garantía de éxito.

En el pensamiento expresado por el padre mayor de la Casa de la Misericordia también estaba el recompensar el futuro trabajo de Valdés Leal, además de con los aludidos 500 ducados, con la concesión a sus cuatro hijas "naçidas en San Martín y San Andrés" de otras tantas dotes pertenecientes al patronato fundado por Pedro Pérez de Guzmán ${ }^{14}$. Los cofrades reunidos en aquel cabildo de febrero de 1668 decidieron formar una diputación particular para este asunto del retablo mayor, "que lo traten y confieran, assí con artistas por lo que toca a la fábrica, como con theólogos la aplicaçión de lo que se ubiere de gastar, a qué bolças o dotaçiones, y de lo que

10 Recientemente estudiados por Herrera, 2015: 161-163.

11 A este respecto, véase, por ejemplo, Falcón, 1991: 154-155.

12 AHPSE, Hospital de la Misericordia, Libro 19, Libro de Acuerdos 1666-1675, f. 66r.

13 De todo ello se da cumplida información en Roda, 2001: 51-64.

14 AHPSE, Hospital de la Misericordia, Libro 19, Libro de Acuerdos 1666-1675, f. 66r. En realidad, solo tres de sus cuatro hijas habían sido bautizadas en las parroquias hispalenses de San Martín (Eugenia María, 1657) y San Andrés (María de la Concepción, 1664; Antonia Alfonsa, 1667), puesto que la primogénita, Luisa Rafaela, recibió las aguas bautismales en la parroquia de San Pedro de Córdoba, en 1654. Gestoso, 1916: 39, 89 y 91-92. Valdivieso, 1988: 17, 19 y 21. 
confirieren y trataren den quenta a el Cavildo para que tome la resoluçión que convenga", nombrándose por diputados, entre sus hermanos, al marqués de Valencina, al caballero de la Orden de Alcántara y veinticuatro de Sevilla Alonso Verdugo de Albornoz — retratado en su adolescencia inicial por Zurbarán (Berlín, Staatliche Museen zu Berlin, Gemäldegalerie)_, al alcalde mayor de Sevilla Pedro Caballero de Illescas, al capitán Juan de Santo Domingo y a los ya citados Francisco Ortiz de Godoy y Juan de Saavedra Alvarado ${ }^{15}$, a los que se añadieron tres más, designados en la siguiente reunión capitular celebrada el Viernes Santo 30 de marzo de ese mismo año: el veinticuatro Luis Manuel de Céspedes, el marqués de Villamanrique y Luis Federigui, caballero de la Orden de Calatrava, señor de la villa de Paterna del Campo y alférez mayor de Sevilla ${ }^{16}$.

Como primera providencia, la comisión acordó el 7 de abril de 1668 aplicar a la "fábrica y obra del retablo" los residuos de la renta anual que generaba la generosa dotación fundada por Alonso de Montalbán, incluidos los 3000 reales de plata que solían destinarse a la "redempçión de captivos el año que no fuere redempçión de la merced calçada"17. Para salvar el problema de conciencia y hasta legal que ello pudiera suscitar, se acudió al sabio parecer del jesuita Francisco de Silva "que vivió, y murió en esta Casa Professa [de Sevilla] con opinión de Varón docto, y muy espiritual", en palabras de su contemporáneo Gabriel de Aranda, miembro también de la Compañía de Jesús ${ }^{18}$. Su largo y erudito dictamen se leyó por los diputados el 12 de mayo, respaldando aquella pretensión con sesudos argumentos teológicos y jurídicos, cuya clave radicaba en la consideración del retablo que se pretendía construir como "obra pía" que justificaba la detracción de recursos de aquel patronato ${ }^{19}$. Solventado este punto, verdaderamente crucial para asegurar la financiación de la obra, dieron su visto bueno a "la planta que trajo a la mesa el Señor Padre Maior de la fábrica del retablo", devolviéndosele "para que ajuste el preçio y de lo que ajustare dé quenta al Cavildo, a quien se remiten todos los acuerdos desta Junta y dichos pareceres" 20 . Nada se dice a propósito de las características o autoría de esta planta presentada ahora por el padre mayor para su aprobación; no obstante, pensamos que sería distinta a la que meses antes, en febrero, él mismo le había solicitado a Valdés Leal, quien, como ya vimos, tuvo que adaptarse al limitado presupuesto de 500 ducados que, en un principio, pensaban emplearse en su realización. Ahora el panorama había cambiado notablemente, se daba curso a un proyecto mucho más ambicioso y, según veremos, el retablo mayor terminaría contratándose por 3500 ducados, por lo que también parece razonable pensar en la elaboración de un nuevo diseño para el mismo, que no solo fuese "digno", como el planteado anteriormente, sino más acorde con esa "grandesa competente" a la que los cofrades de la Misericordia aspiraban. A quién se encomendara este dibujo, resulta una incógnita difícil de resolver, sin descartar la posibilidad de que fuese al propio Valdés; lo que podemos adelantar es que no fue a Bernardo Simón de Pineda, quien al concertar el retablo se obliga a sujetarse a "una traza que para ello se me a entregado" por parte de los responsables de la Casa Hospital.

La siguiente junta de la comisión tuvo lugar el 22 de julio de 1668, y en su transcurso se tomaron dos importantes resoluciones: la primera, consignar 37175 reales procedentes de la dotación de Alonso de Montalbán "para la fábrica del retablo de la yglesia desta Santa Casa", y en segundo lugar, facultar al padre mayor, en unión de Pedro Caballero de Illescas y Juan de Santo Domingo, para que concertasen dicha máquina lignaria "como más convenga, y con las condiçiones y seguridad, adelantamiento de dinero y tiempo, plazo precisso, pena condiçional y las demás condiçiones que les pareciere", contando con el asesoramiento legal de Francisco Ortiz de Godoy ${ }^{21}$.

\footnotetext{
15 AHPSE, Hospital de la Misericordia, Libro 19, Libro de Acuerdos 1666-1675, f. 66v.

16 AHPSE, Hospital de la Misericordia, Libro 19, Libro de Acuerdos 1666-1675, f. 69r.

17 AHPSE, Hospital de la Misericordia, Libro 19, Libro de Acuerdos 1666-1675, f. 78r.

18 Aranda, 1683: 310 .

19 AHPSE, Hospital de la Misericordia, Libro 19, Libro de Acuerdos 1666-1675, ff. 78v-96v.

20 AHPSE, Hospital de la Misericordia, Libro 19, Libro de Acuerdos 1666-1675, f. 96v.

21 AHPSE, Hospital de la Misericordia, Libro 19, Libro de Acuerdos 1666-1675, f. 97.
} 
A los pocos días, el 28 de julio, se otorgó el contrato del retablo mayor ante el escribano público Bernardo García ${ }^{22}$. El contenido de dicho documento fue extractado por Gestoso en $1916^{23}$, quien extrajo de su lectura una serie de conclusiones acerca de la paternidad artística del conjunto, erróneas a nuestro parecer, que después ha venido repitiendo rutinariamente casi toda la historiografía posterior. En efecto, el ilustre polígrafo, aun reconociendo que en tal escritura comparecía el "maestro arquitecto" Bernardo Simón de Pineda (1637-c. 1703) como "principal cumplidor y obligado", presentando como sus fiadores al ensamblador Andrés Montero y al pintor de imaginería Juan de Valdés Leal, sin embargo él deduce que "es indudable que dicha obra tomáronla a su cargo los tres, teniendo a su cuidado Valdés, probablemente, las partes del dorado y del estofado, en que fue tan hábil" "24. No sabemos si Bernardo Simón pudo recurrir a la ayuda de Andrés Montero en la construcción del retablo, pero lo que es completamente incierto es que Valdés se ocupara de dorarlo y estofarlo ${ }^{25}$, pues esta tarea, junto a la policromía de sus esculturas, no se produjo sino hasta más de cincuenta años después de haberse culminado su labor de talla, como señalaré más tarde. También pensaba Gestoso que la traza del retablo se debía a Bernardo Simón, cuando en realidad, según advertimos líneas atrás y declara explícitamente la escritura del concierto, aquella le había sido entregada "a mí el dicho prinsipal firmada de los señores Don Diego Cavallero de Cabrera, Padre Mayor de la dicha Casa y Don Pedro Cavallero de Yllescas y Juan de Santo Domingo, Hermanos de la dicha Cassa y Cavalleros Diputados para este negocio y rubricado por el pressente escrivano". De esta circunstancia ya se apercibió el profesor Herrera García, quien perspicazmente intuyó que, al no ser el maestro antequerano el responsable del diseño - algo casi excepcional en su trayectoria-, "quizás ello explique cierto distanciamiento de las propuestas tradicionales de Pineda, especialmente la falta de sentido escenográfico del cuerpo central, si bien no podemos ignorar las dificultades del marco arquitectónico, consistente en una cabecera estrecha y muy vertical" 26 .

Por medio de este contrato, Bernardo Simón de Pineda se obligaba "de haser y que aremos a ttoda costa de madera y manifatura el retablo de arquitectura y escultura y talla para el altar mayor de la yglesia de la dicha Casa de la Misericordia de ttodo el altto y ancho de su fachada", por un precio de 3500 ducados de vellón, de los que 1000 habría de cobrarlos por adelantado, otros 1500 en el decurso de su realización y los 1000 restantes estando acabado e instalado a plena satisfacción "de los dichos Señores Diputados y de los maestros que para ello se nombraren por parte de la dicha Casa de la Misericordia"27. Se estipulan, a continuación, una serie de condiciones por las que se regiría el cumplimiento de esta obligación. La primera, que el banco, el sagrario y el ornato o marco para el lienzo tardomanierista de la Virgen del Pozo Santo - pintado en 1605 por Vasco Pereira ${ }^{28}$ - que habría de presidir el cuerpo principal del retablo, deberían estar asentados para el 25 de diciembre de ese mismo año de 1668. La fecha límite para la colocación del resto del retablo, enteramente concluido "así de ensanblaxe como de escultura", se fija para el 8 de septiembre de 1669, fiesta de la Natividad de Nuestra Señora. Simón de Pineda se comprometía a ejecutar la traza que le había sido entregada sin apartarse un ápice de ella, empleando en su manufactura madera de borne y cedro "y las demás que se usan, sin que ayamos de poner ni pongamos otro género de madera de ynferior calidad"29 (fig. 1).

Singular trascendencia revestía la cláusula referida a la escultura "de los ssantos y niños y serafines que a de tener el dicho retablo conforme a la dicha traza", cuyo coste estaba compren-

${ }^{22}$ AHPSE, Protocolos Notariales, Leg. 590, ff. 954r-957v.

23 Gestoso, 1916: 97-99.

24 Gestoso, 1916: 97.

25 Siguiendo el criterio de Gestoso, también consideraron a Valdés Leal como el dorador de este retablo, entre otros, Du Gué, 1960: 42. Ferrer, 1982: 25. Halcón, 2000: 26; 2009: 227-228. Dávila/Pérez, 2008: 134. En cambio, Kinkead, 1978: 175 y Valdivieso, 1988: 21, aciertan en esgrimir únicamente su condición de fiador en aquel contrato.

${ }^{26}$ Herrera, 2004: 199.

27 AHPSE, Protocolos Notariales, Leg. 590, f. 954r-v.

28 Serrera, 1995: 76.

29 AHPSE, Protocolos Notariales, Leg. 590, f. 954v. 


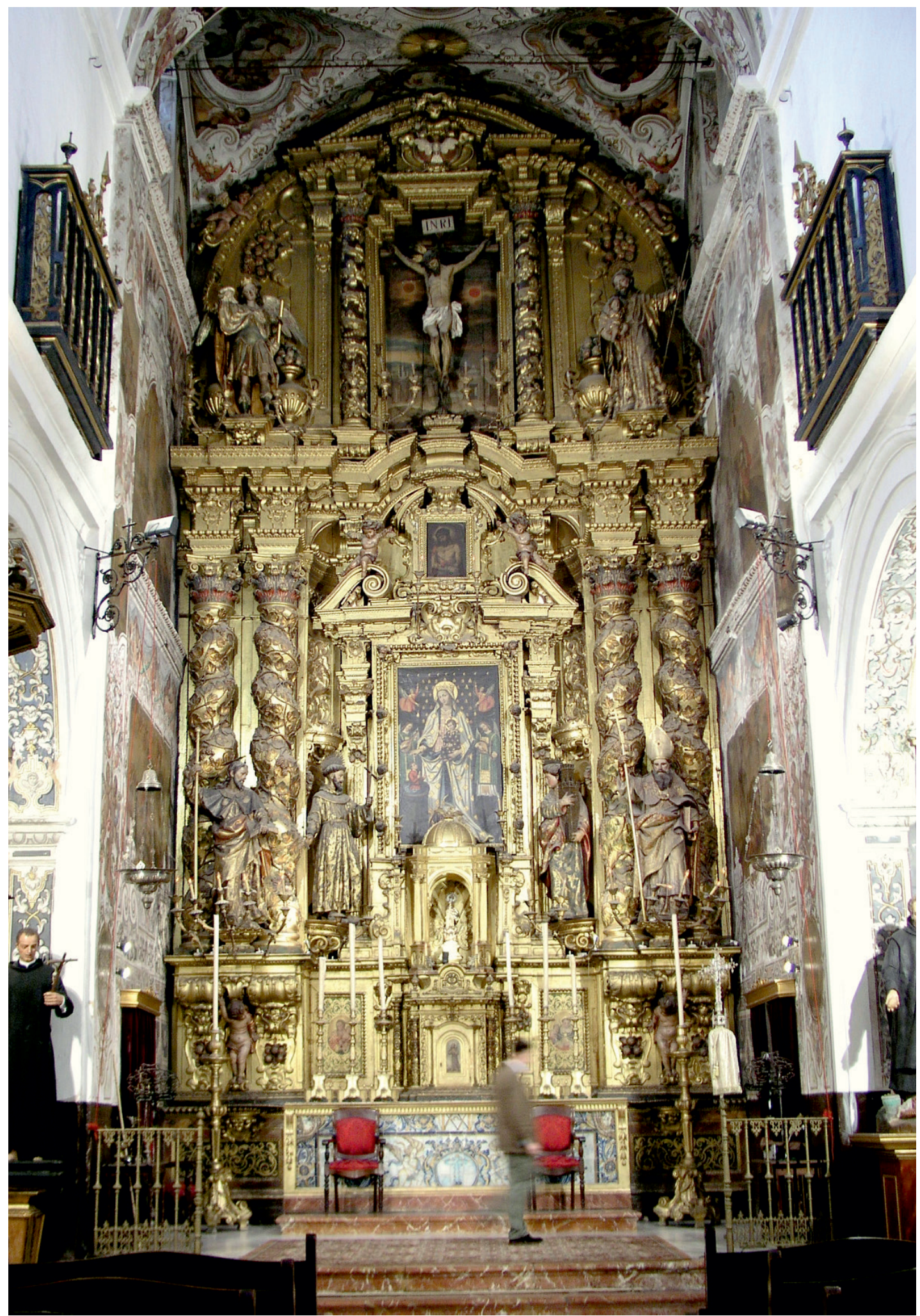

Fig. 1. Bernardo Simón de Pineda. Retablo mayor de la iglesia del hospital de la Misericordia de Sevilla. 1668-1670. Foto: Francisco J. Herrera García. 
dido en el global de 3500 ducados, y que había "de ser echa por mano de los mejores maestros que ai en esta ciudad y en particular por Pedro Roldán o Alfonso Martín o otro semejante a ellos"30. En cuanto a los referidos santos de escultura, se determina su condición de bultos redondos, su ubicación e iconografía que, según se expresa, implicaba alguna variante respecto a lo indicado en el diseño entregado, quedando del siguiente modo: "a el lado del ebangelio son el Patriarca San Josephe y Santiago y San Isidro Arsobispo de Sevilla y al lado de la epístola San Miguel, San Francisco Seráfico y Santa Bárbara"31.

Siguen las habituales condiciones garantistas que prevén que Simón de Pineda no podría exigir mayor remuneración en caso de excederse "de lo que está trazado en talla y escultura", o viceversa, si se detectaba la falta de alguna pieza en el retablo, se vería forzado a realizarla o se le descontaría de su retribución final. Ni él ni sus fiadores podrían alegar engaño en ninguno de los términos sustanciados en el contrato, puesto que todos ellos eran "perssonas peritas en el dicho arte y que lo entendemos y sabemos muy bien y los precios de las maderas y de la manifatura y el tiempo que puede durar esta obra". Se insiste en que, antes de recibir la última paga, todas las formalidades pactadas en este protocolo en cuanto a plazos, calidad de los materiales, sujeción a la traza, etc., estarían debida y enteramente cumplidas, hasta el punto de que no siendo así, consentían en que, corriendo ellos con los gastos, los representantes de la Casa de la Misericordia pudieran concertar con otros maestros y por cualquier cantidad todo aquello que fuese menester para su perfecto acabado ${ }^{32}$.

No había transcurrido ni una semana de la firma del concierto anterior cuando, el 3 de agosto de 1668, Bernardo Simón de Pineda y Juan de Valdés Leal - a quienes unía, amén de una relación profesional que venía de más lejos, una vinculación afectiva de compadres desde que el 20 de febrero de 1667 el retablista apadrinase a Antonia Alfonsa, hija del pintor ${ }^{33}$ - concurrieron a la misma escribanía de Bernardo García para incrementar la cuantía y calificación de sus avales, dando así mayor seguridad jurídica al contrato del retablo, de manera que además de la obligación general de sus personas y bienes, ahora Bernardo hipotecaba "la mejora y más valor de renta de las casas de mi morada que las tengo en arrendamiento por tiempo de tres vidas susesibas del conbento de San Gerónimo extramuros desta ciudad en presio de un mill y ducientos reales de renta en cada un año" y Valdés hacía lo propio con "las casas en que vibo que las tengo por dos bidas de los Señores Deán y Cavildo de la Santa Yglesia desta ciudad en dusientos reales de renta en cada un año"34.

Bernardo Simón de Pineda aprovechó ese mismo día su presencia ante el notario para otorgar la primera de sus cartas de pago "a los Señores Padre Mayor y hermanos de la Casa Ospital de la Misericordia desta ciudad y al Señor Don Joseph de Séspedes hermano y Thesorero de la dicha Casa" por la apalabrada suma inicial de 11000 reales $^{35}$. Ahora estamos en condiciones de asegurar que esos mil ducados "para la fábrica del retablo" procedían de la dotación fundada por

30 AHPSE, Protocolos Notariales, Leg. 590, ff. 954v-955r.

31 AHPSE, Protocolos Notariales, Leg. 590, f. 955r. Esta localización iconográfica, como ya señaló Ferrer, 1982: 25-26, discrepa de la que puede verse en el retablo, donde aparecen, en el lado del evangelio, San Miguel, Santiago y San Francisco; y en el de la epístola, San José, Santa Bárbara y San Isidoro. La presencia de estos seis santos no es arbitraria, ya que la Casa de la Misericordia celebraba fiestas en honor de todos ellos, por cuenta de una serie de dotaciones establecidas al efecto. Centra el ático un Crucificado que no se menciona en la escritura contractual.

32 AHPSE, Protocolos Notariales, Leg. 590, ff. 955r-v. El contrato fue firmado el 28 de julio de 1668 por Bernardo Simón de Pineda y Juan de Valdés Leal, mientras que los diputados de la Casa de la Misericordia signaron este protocolo unos días después, el 3 de agosto.

33 Pocos meses después, el 10 de mayo de 1667, Simón de Pineda actúa como fiador de Valdés Leal en el contrato para la realización del dorado del retablo mayor de la iglesia conventual de San Antonio de Padua de Sevilla, así como de las pinturas murales de su presbiterio. Gestoso, 1916: 91-93. Kinkead, 2007: 539.

34 AHPSE, Protocolos Notariales, Leg. 590, f. 960. Citado por Gestoso, 1916: 99 y extractado, con errores de transcripción, por Kinkead, 1978: 550; 2007: 541.

35 AHPSE, Protocolos Notariales, Leg. 590, f. 973. AHPSE, Hospital de la Misericordia, Leg. 311, Libranzas, cartas de pago, justificantes 1668. La carta de pago fue dada a conocer, sin aludir a la cantidad abonada, por Gestoso, 1916: 99. 
Lorenzo Verdugo que administraba este establecimiento hospitalario, contándose para secundar moral y legalmente dicha aplicación económica con el informe favorable emitido una vez más por el jesuita Francisco de Silva ${ }^{36}$. La siguiente carta de pago se protocolizó el 3 de enero de 1669, cobrando 6406 reales y un cuartillo de vellón, "por quenta de la cantidad en que estoy obligado a haser de ensanbladura y escultura el retablo para el altar mayor de la yglesia de la dicha Casa de la Misericordia" ${ }^{37}$, detraídos en esta ocasión de la ya mencionada dotación de Alonso de Montalbán ${ }^{38}$.

En el cabildo general celebrado el 10 de marzo de 1669, el padre mayor se hizo eco de la falta de medios "para acabar el retablo de la yglesia desta Santa Casa", de manera que propuso asignar a este propósito los 6006 reales que previamente habían sido entregados por Miguel Mañara y Vicentelo de Leca al tesorero de la corporación "para que se distribuiesen a la voluntad deste cavildo", aprobándose así por los concurrentes ${ }^{39}$. Resulta del mayor interés advertir la presencia benefactora del virtuoso e ilustre caballero de la Orden de Calatrava en el seno de la Casa de la Misericordia, contribuyendo a sufragar del modo descrito la construcción de este retablo mayor que precedió al que, inmediatamente después de haberse concluido, se erigió por iniciativa del propio Mañara en la cabecera de la iglesia de San Jorge del hospital de la Santa Caridad de Sevilla, institución en la que venía ejerciendo como hermano mayor desde finales de 1663, concertándolo también con Bernardo Simón de Pineda el 19 de julio de $1670^{40}$ (fig. 2).

Gracias a la limosna de Miguel Mañara, complementada con otros recursos, pudieron librarse al maestro ensamblador dos nuevas cartas de pago: la primera, por valor de 2200 reales, el 9 de agosto de $1669^{41}$; y la segunda, de 4400 reales, el 16 de diciembre de ese mismo año ${ }^{42}$. Con los 3493 reales y tres cuartillos en moneda de vellón que se le abonaron por cuenta de la dotación de Alonso de Montalbán el 28 de febrero de 1670, se completó la segunda entrega que, por un total de 16500 reales, se había estipulado pagarle en el contrato, "en el discursso de la obra del retablo que estoi haziendo" 43 . Por fin, el 25 de junio de 1670, Bernardo Simón de Pineda declara haber recibido 11000 reales "que son de resto cumplimiento y entera paga a los tres mil y

36 AHPSE, Hospital de la Misericordia, Libro 19, Libro de Acuerdos 1666-1675, f. 103v. Libro 132, Libro de ingresos y gastos de arcas corrientes 1667-1668, f. 183r.

37 AHPSE, Protocolos Notariales, Leg. 592, f. 16r.

38 AHPSE, Hospital de la Misericordia, Libro 132, Libro de ingresos y gastos de arcas corrientes 1667-1668, f. 201v. "A Bernardo Simón Maestro escultor 6400 reales y quartillo que valen 217812 maravedíes por quenta de los 3500 ducados de vellón los que se concertó la obra de madera del retablo de esta Santa Cassa y esta cantidad se a de aplicar a la dispocissión de pressos y cautivos de la dotacción de Alonso de Montalván y a de salir del residuo de dicha dispocissión a fin de diziembre de 1667 en conformidad de las consultas hechas y de los acuerdos del cavildo de esta Santa Cassa”.

39 AHPSE, Hospital de la Misericordia, Libro 19, Libro de Acuerdos 1666-1675, f. 120v.

40 El contrato del retablo mayor de la Caridad, donde además se encomienda todo su ciclo escultórico a Pedro Roldán, lo publicó López, 1928: 99-102.

41 AHPSE, Protocolos Notariales, Leg. 593, f. 956. AHPSE, Casa Hospital de la Misericordia, Leg. 312, Libranzas, cartas de pago, justificantes 1669-1670. Libro 133, Libro de ingresos y gastos de arcas corriente 1669-1670, f. 122v. "A Bernardo Simón maestro arquitecto vecino de esta ciudad 2200 reales de vellón que valen 74800 maravedíes por quenta de los 16500 reales de la 2. a paga que se le an de dar para la obra de madera del retablo que está haciendo para la Yglesia de esta Santa Cassa".

42 AHPSE, Protocolos Notariales, Leg. 594, f. 846. AHPSE, Hospital de la Misericordia, Leg. 312, Libranzas, cartas de pago, justificantes 1669-1670. Libro 133, Libro de ingresos y gastos de arcas corriente 1669-1670, f. 143. "A Bernardo Simón Maestro Arquitecto vecino de esta ciudad 4400 reales de vellón valen 149600 maravedíes a quenta de los 16500 reales en que tiene consertado y está obligado a haçer el retablo del altar maior de la Ygleçia de esta Santa Cassa".

43 AHPSE, Protocolos Notariales, Leg. 595. AHPSE, Hospital de la Misericordia, Leg. 313, Libranzas, cartas de pago, justificantes 1670-1671. Libro 133, Libro de ingresos y gastos de arcas corriente 1669-1670, f. 182v. "A Bernardo Simón maestro ensamblador veçino de esta ciudad a cuio cargo está la obra del retablo del Altar maior de la Yglecia de esta Santa Cassa 3493 reales de vellón que valen 118787 maravedíes de resto de los 16500 reales que se le an de pagar por la 2. ${ }^{a}$ paga de los 38500 reales en que está concertada la obra del dicho retablo por quenta de la dottación del Señor Alonso de Montalván tocante a la dispocissión de pressos y cautivos y por quenta de los ressiduos que se deven fin de diciembre de 1667". 
Fig. 2. Bernardo

Simón de Pineda,

Pedro Roldán y

Juan de Valdés Leal.

Retablo mayor de la iglesia del hospital de

la Santa Caridad de

Sevilla. 1670-1673.

Foto: José Carlos

Pérez Morales.

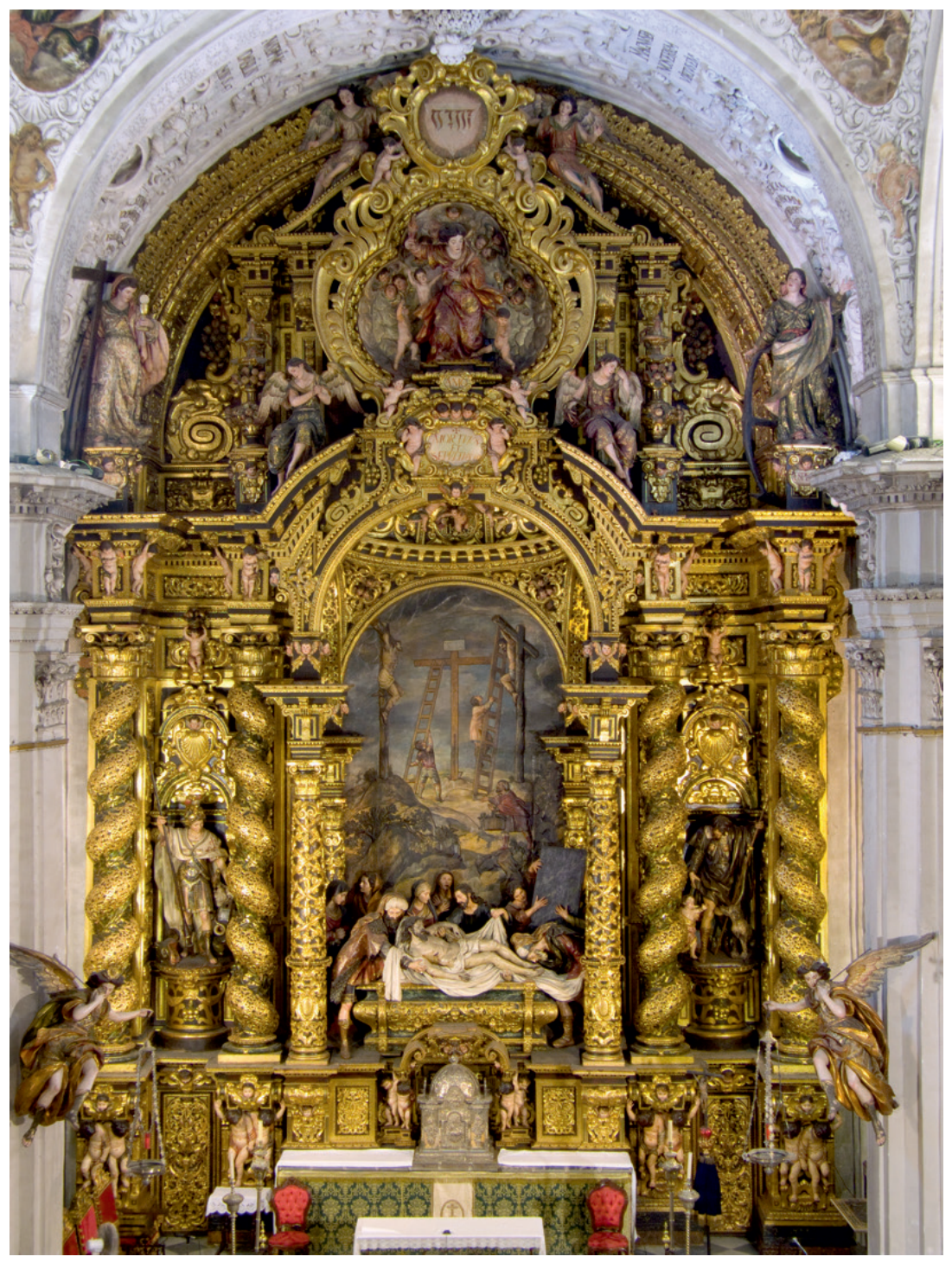

quinientos ducados en que me obligué a hacer como con efecto e echo un retablo para el altar mayor de la dicha Cassa de la Misericordia"44.

Otros desembolsos de última hora hacen referencia a las varas de hierro con sus respectivos pescantes que servían para la colocación de velos de tafetán morado, carmesí o blanco, adornados con galones y puntas de encaje dorado, destinados a cubrir algunas de las imágenes escultóricas y pictóricas del retablo mayor en determinados tiempos o fiestas litúrgicas ${ }^{45}$. De inmediato, entre

${ }^{44}$ AHPSE, Protocolos Notariales, Leg. 596, f. 633. AHPSE, Hospital de la Misericordia, Leg. 313, Libranzas, cartas de pago, justificantes 1670-1671. Libro 133, Libro de ingresos y gastos de arcas corriente 1669-1670, f. 192. “A Bernardo Simón maestro ensamblador vecino de esta çiudad 11000 reales de vellón que valen 374000 maravedíes de resto y a cumplimiento a los 3500 ducados de vellón en que se consertó la obra del retablo del altar maior de la ygleçia de esta Santa Cassa que a hecho y puesto en ella".

45 Al maestro cerrajero Tomás de Arciniega se le pagaron 120 reales el 11 de marzo de 1670, "por el valor de seis barras de fierro y seis pescantes con sus porqueçuelas que a hecho para los velos que se an de poner en el Altar maior 
los meses de julio y septiembre de 1670 , se procedió al dorado del interior del sagrario, pieza que centra el banco de su estructura arquitectónica, recayendo dicha tarea en el "maestro estofador" Francisco de Fonseca, por un monto de 500 reales $^{46}$. Un lustro más tarde, y como mobiliario eclesiástico complementario del retablo mayor, se encargó a Bernardo Simón de Pineda la talla en madera de dos atriles y unas gradillas, cuyo costo de 1200 reales se le satisfizo entre octubre de 1675 y comienzos de $1676^{47}$, mientras que su dorado se confió a Juan de Valdés Leal por una suma de 1600 reales $^{48}$.

Desde el pionero análisis de Hernández Díaz, pasando por los de Paulina Ferrer y los últimos de Fátima Halcón, se ha señalado la importancia de este retablo en el catálogo de Bernardo Simón de Pineda, así como el hecho de que su composición general aparezca determinada tanto por su adaptación a un testero plano, muy alto y estrecho, cuanto por la representación pictórica de la Virgen del Pozo Santo, que preside su cuerpo principal ${ }^{49}$ (fig. 3). En efecto, el lienzo se presenta, en la calle central, encajado en una suerte de pequeño retablo-marco con su moldura tachonada de cabezas de querubes, entre sendas pilastras corintias, y rematado por un frontón partido de volutas enrolladas sobre las que reposan dos ángeles niños que escoltan un cuadrito del Ecce Homo situado en la clave. Tal dispositivo queda retranqueado respecto a las parejas de monumentales columnas salomónicas que, con sus giros invertidos entre sí, determinan las angostas entrecalles laterales; dicho soportes, de cinco espiras y media, muestran una envolvente decoración de sarmientos, hojas, zarcillos y racimos de uvas. Otras dos columnas corintias, esta vez con sus fustes cilíndricos retallados, flanquean la caja central del amplio ático (fig. 4), presentando una tipología similar a las de menor formato que ciñen el sagrario del banco, sobre el cual se insertó posteriormente un manifestador de traza neoclásica que cobija una esculturilla de la Inmaculada. El tránsito hacia dicho coronamiento se practica a través de una potente cornisa que en su tramo medio se alza en un arco roto por su centro. Desde el punto de vista estructural, lo más original es el paso cóncavo que Simón de Pineda introdujo en los extremos de la calle central del cuerpo principal del retablo, lo que le permitió incluir dos esculturas en disposición sesgada a los lados del marco mariano y otras dos más avanzadas, delante de las salomónicas, sugiriéndose mediante dicha orientación un cierto dinamismo espacial que la propia arquitectura lignaria apenas deja atisbada. Por su parte, el repertorio ornamental desplegado sobre la superficie del retablo, a base de hojas y tiras carnosas, tarjas correosas, sartas y jarrones rebosantes de frutas, se sustancia en motivos de apreciable formato, plasmados con una jugosa plasticidad.

de esta Santa Cassa", y otros 30 reales el 19 de junio "por el valor de una bara de fierro con sus pescantes que hiço para la cortina que se a de poner a el Sancto Christo del retablo del Altar maior de esta Santa Cassa". El coste de los tejidos para confeccionar dichos velos ascendió a 700 reales y 13 maravedíes. AHPSE, Hospital de la Misericordia, Libro 133, Libro de ingresos y gastos de arcas corriente 1669-1670, ff. 185v y 201r.

46 AHPSE, Hospital de la Misericordia, Libro 19, Libro de Acuerdos 1666-1675, cabildo general de 6 de julio de 1670, f. 183r. "Acordose de conformidad que luego cuanto antes se dore el sagrario del retablo que se a hecho en esta Santa Cassa por de dentro y se saque el dinero de la parte más pronta que ubiere". Libro 133, Libro de ingresos y gastos de arcas corriente 1669-1670, f. 206r. Leg. 313, Libranzas, cartas de pago, justificantes 1670-1671. En dicho importe se englobaban "los gonçes que se echaron a las puertas del dicho Sagrario".

47 AHPSE, Hospital de la Misericordia, Libro 136, Libro de ingresos y gastos de arcas corrientes 1674-1681, ff. $154 \mathrm{r}, 159 \mathrm{v}$ y $278 \mathrm{v}$. Fueron tres pagos de 300, 300 y 600 reales, estos últimos "por los mismos que el Señor Don Luis Federigui hermano de esta Santa Cassa y diputtado de la ygleçia y sachristía de esta Santa Cassa en virtud de acuerdo de ella le libró de resto de los 1200 reales en que se conzertó la obra de las gradillas y atriles de madera que a hecho para la Ygleçia y altar maior della".

48 AHPSE, Hospital de la Misericordia, Libro 136, Libro de ingresos y gastos de arcas corrientes 1674-1681, ff. 196v-197r y 292v. Primero recibió 600 reales y más tarde otros 1100, “de resto de los 1600 reales en que se concertó el dorado y estofado de dos atriles, gradillas, urna y peana que se hiço para las fiestas del Señor Alonso de Montalván y los 100 reales restantes por el adereço del quadro que está en el Patio de esta Santa Cassa". Pensamos que esta última alusión puede hacer referencia al fresco del Juicio Final, obra de Luis de Valdivieso en 1567, que permaneció en el patio del hospital de la Misericordia hasta la década de los años setenta del siglo pasado, conservándose hoy en los depósitos del Museo de Bellas Artes de Sevilla. Albardonedo, 2003: 80-83.

49 Hernández, 1935: 16-17. Ferrer, 1982: 25-26, 105-111; 1983: 165. Halcón, 2000: 26-28, 295; 2009: 227-228. 


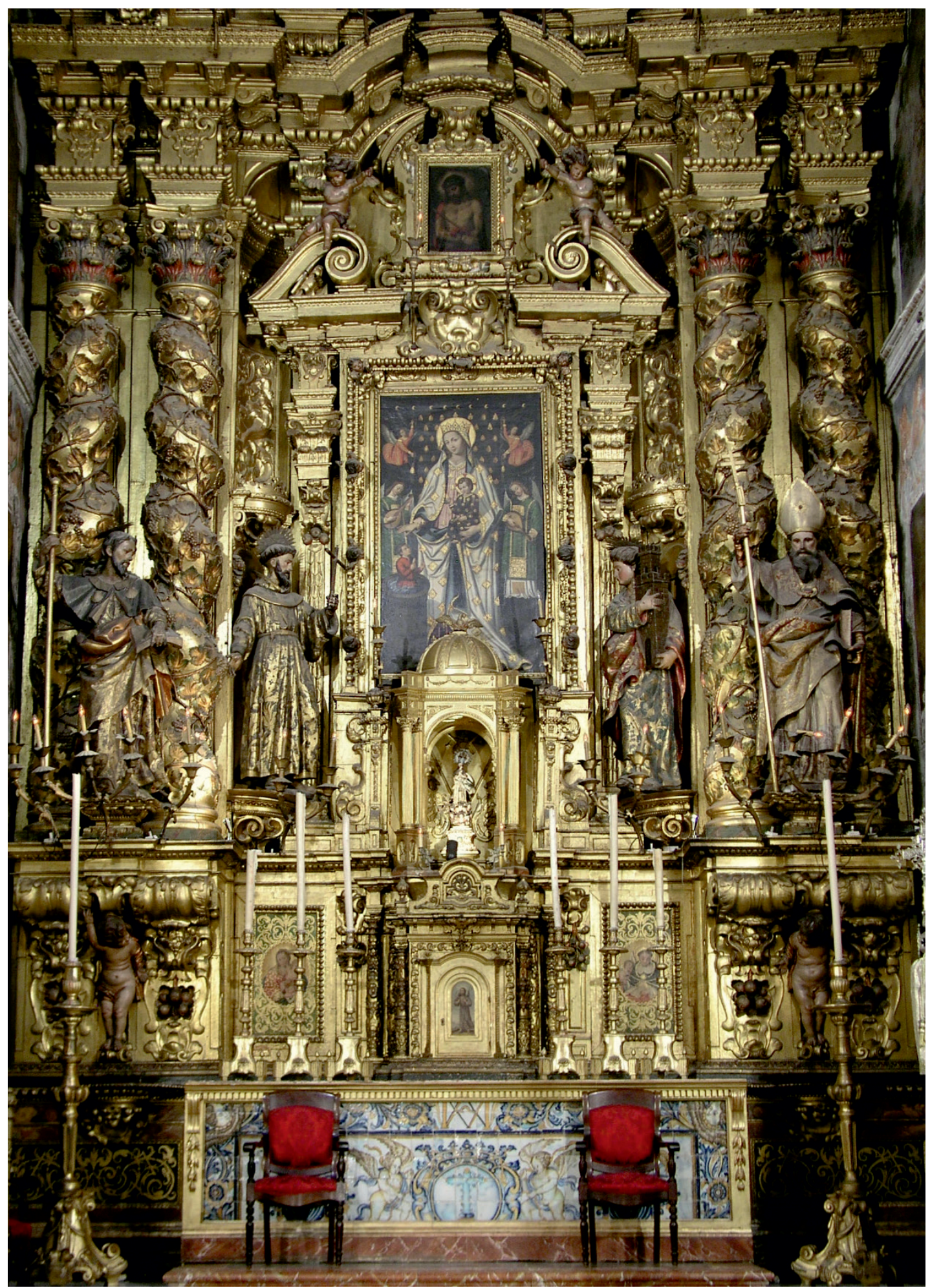

Fig. 3. Bernardo Simón de Pineda y Vasco Pereira (lienzo de la Virgen del Pozo Santo, 1605). Banco y cuerpo principal del retablo mayor de la iglesia del hospital de la Misericordia de Sevilla. Foto: Francisco J. Herrera García. 


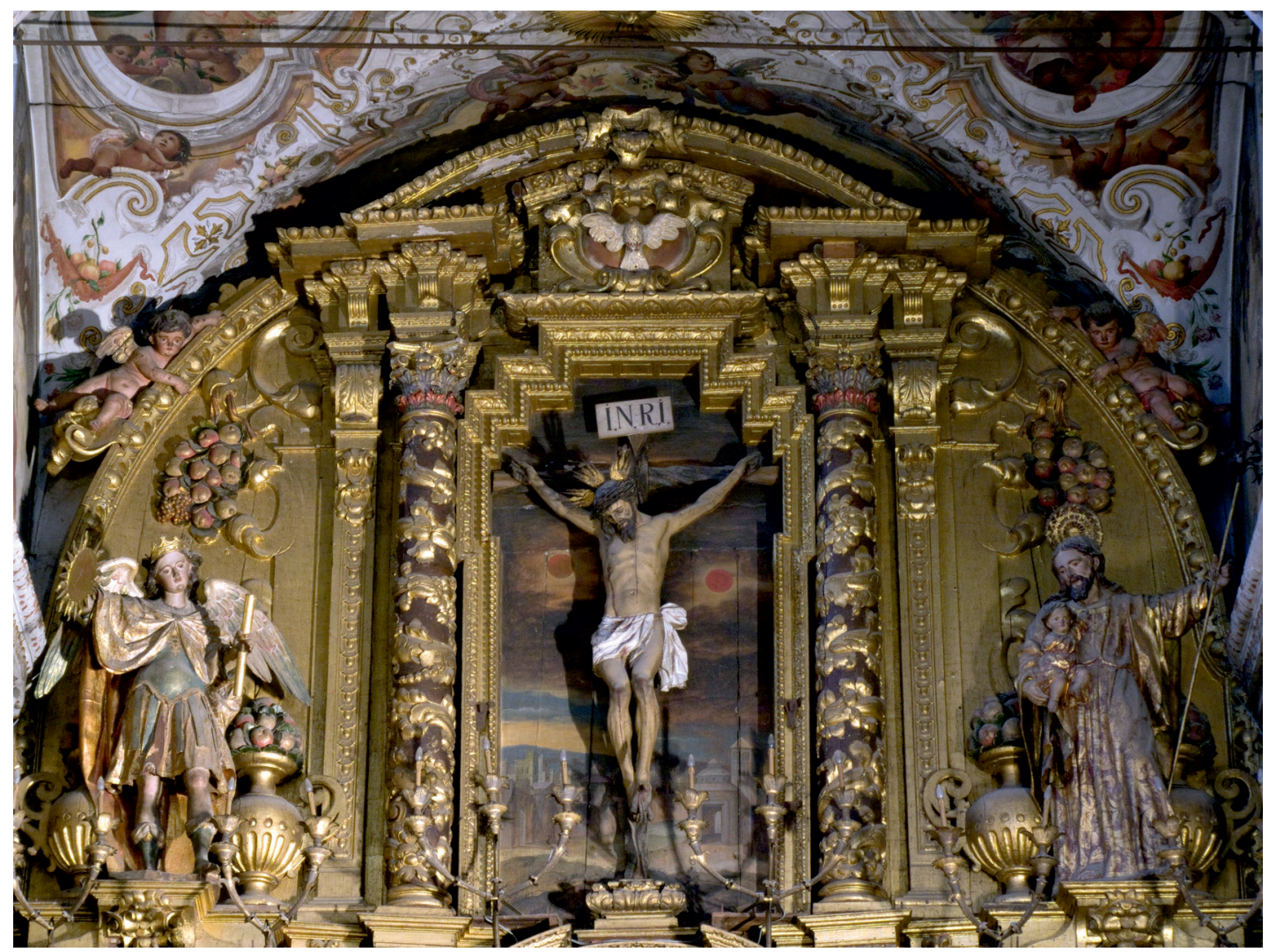

Fig. 4. Bernardo Simón de Pineda. Ático del retablo mayor de la iglesia del hospital de la Misericordia de Sevilla. Foto: José Carlos Pérez Morales.

Ya sabemos cómo en los 3500 ducados que percibió Bernardo Simón de Pineda quedaba incluido el coste de las siete esculturas exentas y de tamaño natural que alberga este retablo: Santiago Apóstol y San Francisco de Asís en el lado del evangelio del cuerpo principal, Santa Bárbara y San Isidoro en el de la epístola (figs. 5 y 6), y en el ático un Crucificado, flanqueado a su derecha por San Miguel Arcángel y a la izquierda por San José, amén de la paloma del Espíritu Santo que, inserta en una cartela, aletea sobre la figura del Cristo, de los dos ángeles atlantes del banco y de algunos más - de bulto y en relieve- que pululan por el resto de la mazonería, explicitándose en el contrato que "la dicha escultura a de ser echa por mano de los mejores maestros que ai en esta ciudad y en particular por Pedro Roldán o Alfonso Martín o otro semejante a ellos". Según ha podido comprobarse, la documentación generada al socaire de su proceso constructivo silencia por completo el nombre del autor de tales imágenes, pero teniéndose en cuenta que no pudo ser Alonso - o Alfonso- Martínez, fallecido a finales de ese mismo año de 1668, hemos de suponer que se trate de un conjunto salido del obrador de Pedro Roldán (1624-1699), como parece denotar su técnica de talla y la morfología que exhiben dichas efigies ${ }^{50}$ (figs. 7 y 8 ).

No cabe duda de que este retablo mayor constituyó un punto clave e inicial en el proceso de barroquización de un templo como este, concebido arquitectónicamente en clave clasicista. Tanto el dispositivo arquitectónico como sus esculturas permanecieron en blanco, esto es, sin dorar ni policromar, durante más de cinco décadas. La idea de afrontar dicha tarea parece ir cristali-

50 Roda, 2012: 299-302. 

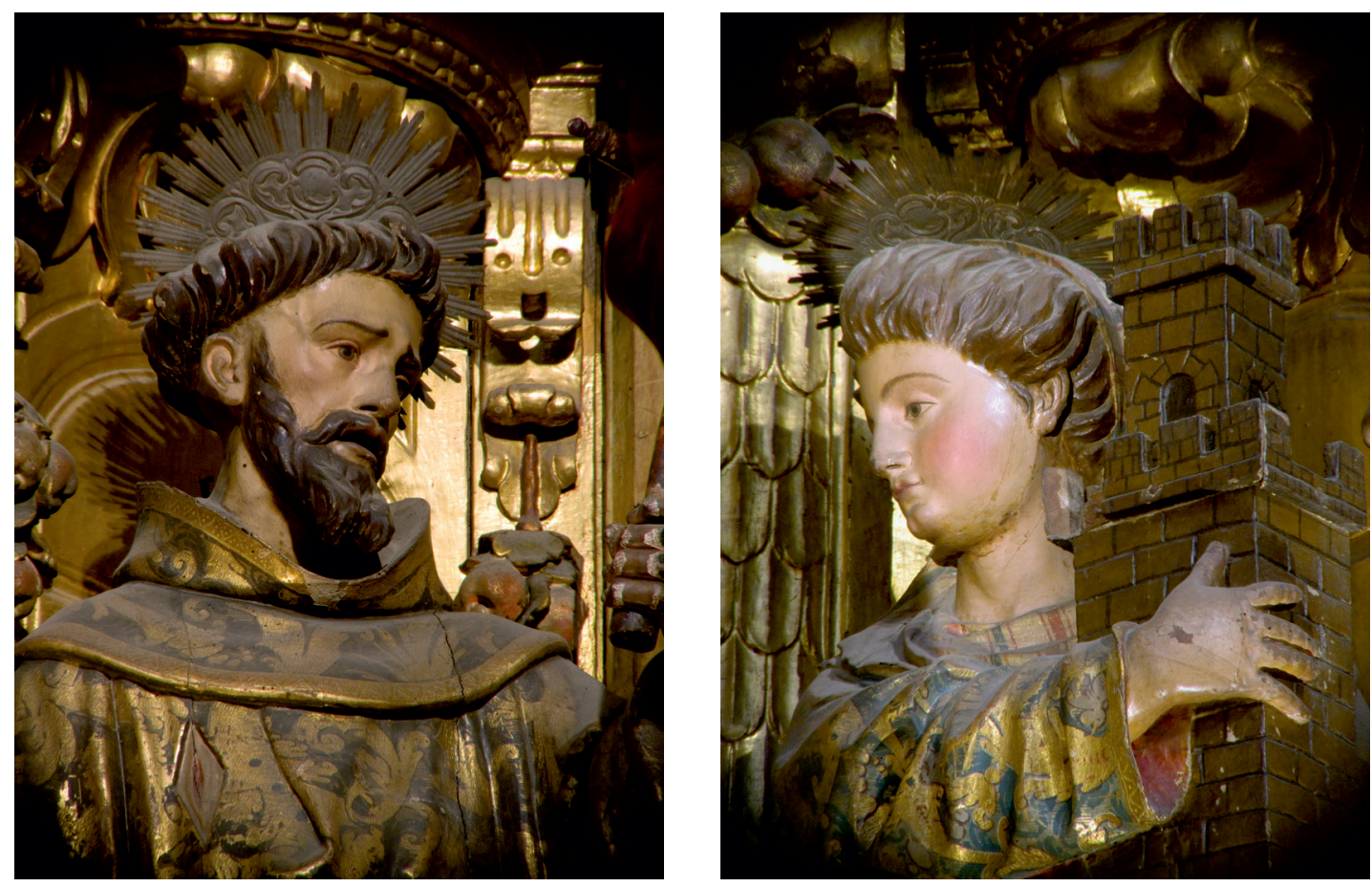

Figs. 5 y 6. Pedro Roldán y taller (atribución). San Francisco de Asís y Santa Bárbara (detalles). Fotos: José Carlos Pérez Morales.
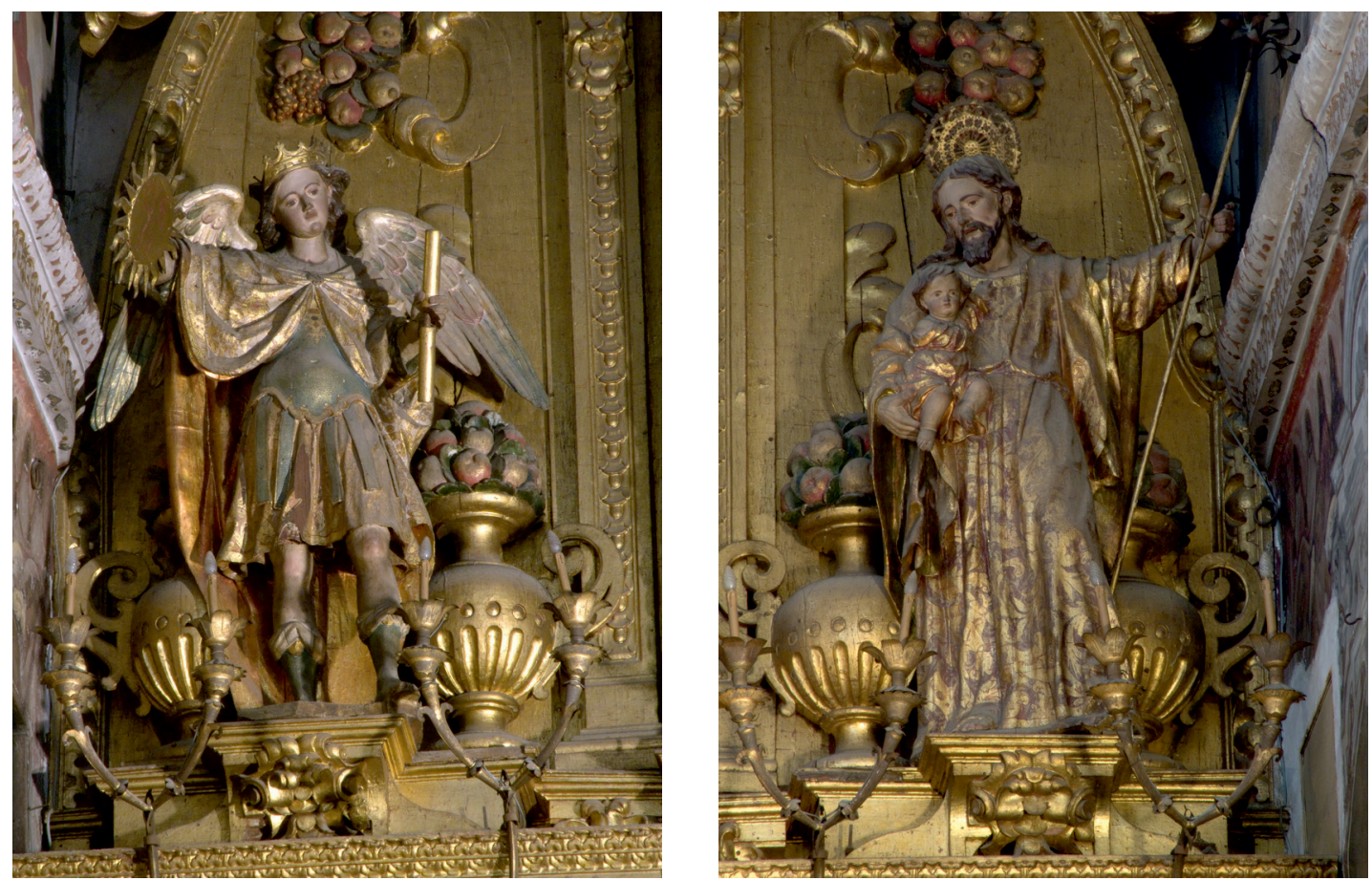

Figs. 7 y 8. Pedro Roldán y taller (atribución). San Miguel Arcángel y San José. Fotos: José Carlos Pérez Morales. 

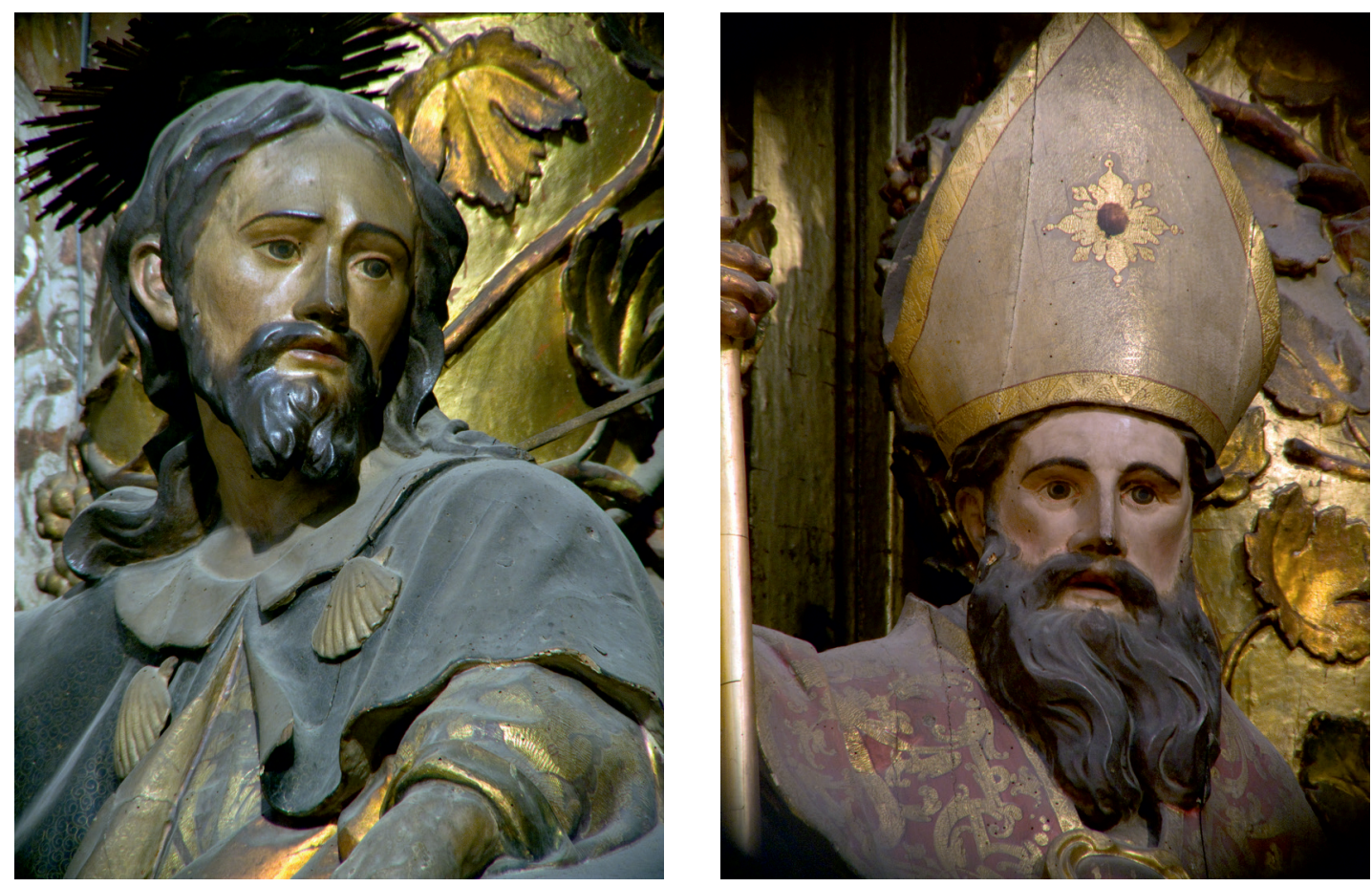

Figs. 9 y 10. Pedro Roldán y taller (atribución). Santiago Apóstol y San Isidoro (detalles).

Fotos: José Carlos Pérez Morales.

zando a partir de 1715, cuando se registra un primer donativo de 60 ducados por parte del marqués de Vallehermoso, que se repetiría por la misma cantidad al año siguiente, "para ayuda al dorado del retablo de la yglesia desta Santa Cassa" ${ }^{51}$. Lo cierto es que los trabajos, inicialmente contratados con el maestro dorador Miguel Delgado Moreno $^{52}$, no dieron comienzo hasta 1723 , cuando el 27 de agosto se le abonaron 30 pesos escudos de plata - equivalentes a 450 reales de vellón-, por cuenta de los 55 en que tenía ajustado "el dorado de las molduras del quadro de Nuestra Señora que está en el retablo de la Yglesia de esta Santa Casa", cobrando el resto de su retribución, una vez cumplida dicha labor, el 1 de octubre ${ }^{53}$. Al poco, el tesorero de la Casa de la Misericordia, que lo era por entonces el marqués de la Motilla, en nombre del padre mayor Gómez de Moscoso, concertó con el mismo artífice el resto del dorado del cuerpo principal del retablo, "de coluna a coluna hasta el Ecce homo, las diademas, potencias, y repizas de los Santos, y retocar lo dorado del Sagrario", así como el "estofar los Santos de dicho Altar" (figs. 9 y 10), todo ello por un montante de 4080 reales que Miguel Delgado cobró el 19 de enero de $1724^{54}$.

${ }^{51}$ Los sesenta ducados entregados de limosna en 1715 y 1716 correspondían a su salario anual como diputado de la contaduría de la Casa de la Misericordia. AHPSE, Hospital de la Misericordia, Libro 164, Libro de ingresos y gastos de arcas corrientes 1714-1715, f. 62v. Libro 165, Libro de ingresos y gastos de arcas corrientes 1716-1717, f. 35r. Libro 23, Libro de Actas Capitulares 1715-1718, cabildo general de 14 de febrero de 1717, f. 254.

52 Nació en 1682, siendo hijo y discípulo del dorador Francisco Delgado Moreno. Entre otros trabajos, en 1732 contrató el estofado de la capilla mayor del hospital sevillano del Amor de Dios, al año siguiente el dorado del retablo de Nuestra Señora de Roca Amador en la iglesia del convento casa grande del Carmen de Sevilla, en 1734 el del retablo mayor del templo conventual de San Agustín de Osuna y en 1738 el del retablo mayor del convento hispalense de San Basilio. Quiles, 1990: 73-76; 2008: 64-65. Quiles/Cano, 2006: 303-304, 306-307. Cornejo, 2006: 368.

53 AHPSE, Hospital de la Misericordia, Leg. 371, Libranzas, cartas de pago, justificantes 1723.

54 AHPSE, Hospital de la Misericordia, Leg. 372, Libranzas, cartas de pago, justificantes 1724. Libro 169, Libro de ingresos y gastos de arcas corrientes 1724-1725, f. 79v. 
Tras seis meses de paralización, en el cabildo general de 18 de junio, tras manifestar el cofrade y conde de Villanueva Jerónimo Manuel de Céspedes "que le parecía era lástima no acavar de dorar el retablo del altar mayor de la Yglesia de esta dicha Casa expecialmente por estar más defectuoso que antes que se començase a dorar", se tomó la determinación de continuar con dicho quehacer e incluso emprender el estofado de la capilla mayor ${ }^{55}$.

Ambos cometidos recayeron en el pintor y muralista sevillano más prolífico y afamado de su generación: Domingo Martínez (1688-1749) ${ }^{56}$. Su materialización se ajustó en 15000 reales, cuya suma se le abonó en cuatro plazos: 4000 reales el 24 de junio, la misma cuantía el 5 y el 25 de agosto, y los 3000 reales restantes el 16 de septiembre de $1724^{57}$. Para pintar al temple la bóveda de arista, paredes laterales e intradós del arco toral de la capilla mayor fue necesario que, con carácter previo, el maestro mayor de las obras de la Casa de la Misericordia, a la sazón Bartolomé Martínez de Aponte, picara y enluciera todos esos paramentos. Simultáneamente, entre el 27 de mayo y el 16 de octubre de 1724, se pagaron al cantero Juan Antonio Blanco los 1050 reales que costaron las piedras de jaspe encarnado y la confección con ellas de las dos gradas por las que se asciende al presbiterio, más 126 reales que se entregaron el 6 de septiembre al maestro cerrajero Luis Rodríguez por las dieciocho cornucopias metálicas que aún permanecen embutidas en el retablo para su iluminación con bujías ${ }^{58}$.

Por fin, el estreno del dorado del retablo y de las pinturas murales de la capilla mayor - cuyo contenido iconográfico aparece centrado por el ejercicio de las obras de Misericordia a través de pasajes bíblicos y hagiográficos, virtudes y jeroglíficos, en comunión con un amplio repertorio de ángeles, pájaros, flores y frutos ${ }^{59}$ - se solemnizó con la celebración de tres días de fiestas el 4,5 y 6 de octubre de 1724, con el Santísimo Sacramento manifiesto ${ }^{60}$.

\section{BIBLIOGRAFÍA}

Albardonedo, Antonio J. (2003): "La iglesia nueva del hospital de la Misericordia. Un proyecto de Asensio de Maeda con importantes colaboraciones (1595-1606)". En: Laboratorio de Arte, 16, Sevilla, pp. 67-105.

Aranda, Gabriel de (1683): Inmortal Memoria del Eminentíssimo Señor, y Excelentiss. Príncipe el Señor D. Augustín Spínola, Cardenal de la S. Iglesia de Roma. Sevilla: Thomás López de Haro.

Carmona, Juan Ignacio (2000): Crónica urbana del malvivir (s. XIV-XVII). Insalubridad, desamparo y hambre en Sevilla. Sevilla: Universidad de Sevilla.

Collantes de Terán, Francisco (1886): Los establecimientos de Caridad de Sevilla, que se consideran como particulares. Apuntes y memorias para su historia. Sevilla: Oficina de El Orden.

Cornejo, Francisco J. (2006): "Noticias de Francisco de Herrera el Viejo en Madrid y del retablo mayor del Colegio de San Basilio, de Sevilla”. En: Archivo Español de Arte, 316, Madrid, pp. 355-370.

Dávila, Álvaro/ Pérez, José Carlos (2008): Pedro Roldán. Vol. II. Sevilla: Ediciones Tartessos.

Du Gué, Elizabeth (1960): Valdés Leal: Spanish Baroque Painter. Nueva York: Hispanic Society of America.

Falcón, Teodoro (1991): "Valdés Leal y la arquitectura sevillana". En: Laboratorio de Arte, 4, Sevilla, pp. 149-168.

Fernández, José (2004): “La pintura mural de Domingo Martínez”. En: Pleguezuelo, Alfonso/ Valdivieso, Enrique (coms.): Domingo Martínez en la estela de Murillo. Sevilla: Fundación El Monte, pp. 57-73.

Ferrer, Paulina (1982): Bernardo Simón de Pineda. Arquitectura en madera. Sevilla: Diputación Provincial de Sevilla.

Ferrer, Paulina (1983): “Retablo mayor”. En: Guerrero, José (com.): Sevilla en el siglo XVII. Madrid: Ministerio de Cultura, p. 165.

55 AHPSE, Hospital de la Misericordia, Libro 25, Libro de Acuerdos 1723-1727, s.f.

${ }^{56}$ Este conjunto de pintura mural ya le fue atribuido por Morales/Sanz/Serrera/Valdivieso, 1981: 152. Posteriormente, ofrecí su documentación para ser publicada por Fernández, 2004: 64-65 y Pleguezuelo, 2004: 244.

57 AHPSE, Hospital de la Misericordia, Leg. 372, Libranzas, cartas de pago, justificantes 1724. En esa última fecha se le libraron además 2620 reales "por el dorado y pintado del púlpito, rexa, frontaleras y demás menudencias que han sido precisas", más 150 reales "por darles de color a los balcones y zelosías que están en la Yglesia y choro alto".

58 AHPSE, Hospital de la Misericordia, Leg. 372, Libranzas, cartas de pago, justificantes 1724.

59 Valdivieso, 2016: 127-129.

${ }^{60}$ AHPSE, Hospital de la Misericordia, Libro 169, Libro de ingresos y gastos de arcas corrientes 1724-1726, ff. 169v-170r. Leg. 372, Libranzas, cartas de pago, justificantes 1724. 
Gestoso, José (1916): Biografia del pintor sevillano Juan de Valdés Leal. Sevilla: Juan P. Gironés.

Halcón, Fátima (2000): "El retablo salomónico". En: Halcón, Fátima/ Herrera, Francisco/ Recio, Álvaro: El Retablo Barroco Sevillano. Sevilla: Universidad de Sevilla/Fundación El Monte, pp. 3-100.

Halcón, Fátima (2009): "El triunfo de la columna salomónica”. En: Halcón, Fátima/ Herrera, Francisco/ Recio, Álvaro: El retablo sevillano. Desde sus orígenes a la actualidad. Sevilla: Diputación Provincial de Sevilla/ Fundación Real Maestranza de Caballería de Sevilla/ Fundación Cajasol, pp. 203-288.

Hernández, José (1935): "Papeletas para la historia del retablo en Sevilla durante la segunda mitad del siglo XVII (Francisco Dionisio de Ribas, Bernardo Simón de Pineda, Fernando de Barahona)". En: Boletín de Bellas Artes, 2, Sevilla: 3-37.

Herrera, Francisco Javier (2004): "Bernardo Simón de Pineda, artifice por sus obras digno de eterna alabanza. Prestigio, proyectos frustrados y obras desaparecidas”. En: Laboratorio de Arte, 17, Sevilla, pp. 189-207.

Herrera, Francisco Javier (2015): “'Según demuestra la traza, planta y montea': aspectos del dibujo aplicado a la retablística en Andalucía Occidental durante la Edad Moderna". En: De Cavi, Sabina (ed.): Dibujo y ornamento. Trazas y dibujos de artes decorativas entre Portugal, España, Italia, Malta y Grecia. Córdoba: Diputación de Córdoba, pp. 155-165.

Kinkead, Duncan T. (1978): Juan de Valdés Leal (1622-1690): His Life and Work. Nueva York/Londres: Garland Publishing, Inc.

Kinkead, Duncan T. (2007): Pintores y doradores en Sevilla 1650-1699. Documentos. Bloomington: AuthorHouse.

López, Celestino (1928): Retablos y esculturas de traza sevillana. Sevilla: Rodríguez, Giménez y C. ${ }^{a}$

Morales, Alfredo J. / Sanz, María Jesús/ Serrera, Juan Miguel/ Valdivieso, Enrique (1981): Guía artística de Sevilla y su provincia. Sevilla: Diputación Provincial.

Pérez, Rafael M. (2014): "El Hospital de la Misericordia en la Sevilla del siglo XVI: caridad, dotes y organización social”. En: Lobo, María Marta/ Esteves, Alexandra/ Silva, Ricardo/ Coelho, José Abilío (coords.): Sociabilidades na vida e na morte (Séculos XVI-XX). Braga: CITCEM-Centro de Investigação Transdisciplinar "Cultura, Espaço e Memória".

Pleguezuelo, Alfonso (2004): "Obras datadas". En: Pleguezuelo, Alfonso/ Valdivieso, Enrique (coms.): Domingo Martínez en la estela de Murillo. Sevilla: Fundación el Monte, pp. 237-271.

Quiles, Fernando (1990): Noticias de Pintura (1700-1720). Sevilla: Ediciones Guadalquivir.

Quiles, Fernando (2008): “La policromía del retablo mayor de San Agustín”. En: Cuadernos de los Amigos de los Museos de Osuna, 10, Osuna, pp. 64-65.

Quiles, Fernando/ Cano, Ignacio (2006): Bernardo Lorente Germán y la pintura sevillana de su tiempo (1680-1759). Madrid: Fernando Villaverde.

Roda, José (2001): "Valdés Leal, escultor. Aportación a su catálogo". En: Laboratorio de Arte, 14, Sevilla, pp. 51-64.

Roda, José (2012): Pedro Roldán, escultor 1624-1699. Madrid: Arco/Libros.

Serrera, Juan Miguel (1995): "Nuevas obras de Vasco Pereira". En: Actas del VII Simposio Hispano-Portugués de Historia del Arte. Badajoz: Gabinete de Iniciativas Transfronterizas, 1995, pp. 75-80.

Valdivieso, Enrique (1988): Juan de Valdés Leal. Sevilla: Ediciones Guadalquivir.

Valdivieso, Enrique (2016): "Pintura Mural del Siglo XVIII en Sevilla". En: Valdivieso, Enrique/ Illán, Magdalena/ Malo, Lina/ Santos, Antonio J.: Pintura mural sevillana del siglo XVIII. Sevilla: Fundación Sevillana Endesa.

Zahino, Luisa (1992): "El archivo de la Casa de Misericordia de Sevilla". En: Archivo Hispalense, 230, Sevilla, pp. 63-80.

Fecha de recepción: 20-III-2017

Fecha de aceptación: 07-VIII-2017

Archivo Español de Arte, vol. XCI, n. ${ }^{\circ} 363$, pp. 237-252, julio-septiembre 2018

ISSN: 0004-0428, eISSN: 1988-8511, https://doi.org/10.3989/aearte.2018.15 